\title{
worldview
}

A JOURNAL OF RELIGION AND INTERNATIONAL AFFAIRS

\section{A CHANGE OF NAME}

With this issue of Worldview we announce a change in the name of the organization under whose auspices it is published. The Church Peace Union will from now on be known as the Council on Religion and International Affairs.

To change the name by which an organization has been known for almost fifty years is no light step, and it has been undertaken only after prolonged consideration. The change, it should be remarked at once, does not mean that the basic goals and ideals of the organization have been altered. They remain what they were when the organization was founded in 1914. The shift in name is, rather, a reflection of and a comment on the great events and vast changes which have taken place throughout the world since that time. Some of these events and changes have caused those unfamiliar with the intent and the work of the organization to find in the name, Church Peace Union, meanings and connotations which were never part of the founders' intentions.

The Church Peace Union was founded by Andrew Carnegie in 1914 as an independent, nonsectarian organization. Those who met to form the group and who were to be charter trustees were leaders of the major religious bodies in the country. It is possible to name only a few of that distinguished group. There was Dr. John R. Mott, Methodist, highly esteemed both here and abroad for his work on the International Committee of the Y.M.C.A. The Right Reverend William Lawrence was then Protestant Episcopal Bishop of Massachusetts and had been both professor and dean at the Episcopal Theological School at Cambridge. The most eminent Catholic in the group was probably the most eminent Catholic in America at that time, James Cardinal Gibbons of Baltimore. Another Catholic who had a keen interest in international affairs was John I. Glennon, Archbishop of St. Louis. Among the Jewish representatives, one of the best known was Emil Hirsch, Rabbi of Sinai Congregation in Chicago and Professor of Rab- binical Literature and Philosophy at the Uni-. versity of Chicago.

But Andrew Carnegie was not the only layman in the group. Marcus M. Marks, the president of the Borough of Manhattan, was very active in the New York Jewish community. James $\mathrm{J}$. Walsh, a doctor, was equally active in Catholic circles, and Shailer Mathews, a Baptist layman, was dean of the Divinity School of the University of Chicago.

While there were many other distinguished members who must go unmentioned, special attention is due Arthur J. Brown, then Secretary of the Presbyterian Board of Foreign Missions. The only living member of that original group, Dr. Brown, now in his hundred and fifth year, continues to serve as active treasurer and to extend his valuable advice and judgment.

This group asserted that there was a great need to work for international-orde $r$ and world-wide peace; that this work could draw aid and sustenance from the principles and insights of the major religions; that, indeed, such work could not be accomplished apart from those principles and insights. The Council on Religion and International Affairs fully concurs in these judgments and will continue in its attempt to bring the best thought of our various religious traditions to bear on the critical and unprecedented international problems of our time.

What has changed since those first days of the organization is the very temper of the time and the nature of the crises with which we now must cope. It would be foolish to mock the optimism of those who, on the very eve of the first conflict we have elected to call a world war, looked forward to an;impending world peace. But we know their optimism canpot be ours, and we are beginning to know in our bones that there exists the very real possibility of a war that could with terrible accuracy be termed a world war. This, of course, is the greatest change that has taken 
place in our perspective on international affairs. But there have been since 1914 other changes, of great but varying significance, which bear upon the change of name.

Since 1914 we have seen Western civilization, whose roots are deep in the Judeo-Christian tradition, wracked by two great wars. We have seen the birth and death of many front groups that have traded with the honorific terms of "peace" and "pacifism," and the death and rebirth of pacifist groups that have found new grounds for their fears and arguments. We have seen the growth and extension of an ecumenical movement that is still difficult to grasp and assess.

Not only these sweeping events, though principally these, have given to the name Church Peace Union various and shifting emphases which have misled those unfamiliar with it. It may be well to state what the organization is not. It is not simply Protestant or only Christian. Our civilization has been formed by and drawn its substance from the Judeo-Christian and Graeco-Roman traditions. When our civilization is threatened, as it clearly is today, we must draw upon the fullest resources which nourish and sustain it. The Council, therefore, is composed of members of our major religions and enlists the contributions of Catholics, .Protestants and Jews, alike.

The Council is not syncretistic. While it is profoundly interested in the various manifestations of the ecumenical movement, its own activity is closer to what has come to be known as the dialogue. Each participant in the work of the Council is expected to speak from within his own religious tradition, to bring his principles and insights to bear upon the political problems that beset us all.

Neither is the organization pacifist. Though some of the most respected contributors to the work of the Council are pacifists, the Council itself recognizes that resistance to evil sometimes demands the use of force. Indeed, much of its concern is preciselv with the conditions under which force as an instrument of national policy is politically desirable and morallv acceptable. But it is also concerned with the grave dangers to which mankind has been exposed bv modern weapons and the limitations which both political and moral principles would place upon production and use.

For all of those reasons the name of Church Peace Union, which has done honorable service over the years, will be relegated to historical accounts of the Council on Religion and International Affairs. But those principles under which the original member joined forces, and which the organization has over the years striven to have realized in the international community, are the principles of the Council still. Brietly stated these include:

The unity of mankind as a creation of God.

The equality of all persons as children of God. The dignity of each person as a child of God.

The responsibility of men for each other.

$\bullet$

The work of the Council is to bring these principles, with all their implications, to bear upon the vast and vexing problems of our international political life. This is no simple task readily accomplished. At times it seems overwhelming, as if the demands of our political life, with its necessary concern for material security and welfare, were incompatible with the demands of a moral order. But this is a conclusion the religious person cannot accept. He cannot simply, despairing of a solution, forgo his duties as a member of the city of man and retire to the purity of a position untouched, unsoiled by the work of political thought and action. Neither can he free himself from the impositions of the moral order and commit himself without reservations to unmeasured political action. He who believes in the city of God knows that though he must achieve his destiny in history and through history, he is not wholly contained by it. This knowledge creates for the believer a tension which is rendered particularly acute by the pressing problems of our time.

But as this tension has causes it also has implications; it is these implications as they extend into the political order that the Council seeks to explore. To this end it has a program of seminars, publications, consultations and associations with other organizations. It brings together for discussion men who have special knowledge and competence in international affairs or religion or both, and it extends their views through its publications. It cooperates with governmental agencies and religious organizations on matters of common interest. Because all these activities are more nearly comprehended by its new name, the organization so long known as The Church Peace Union will henceforth be the Council on Religion and International Affairs. 